\title{
Public Administration and the Challenge of National Development in Nigeria: Issues and Concerns
}

\author{
** Achimugu, Hassan \\ Doctoral Candidate/Lecturer \\ Department of Public Administration \\ Kogi State University, Anyigba-Nigeria \\ hassanachimugu@yahoo.com +234(0)8038132529 \\ ${ }^{* *}$ Corresponding author
}

\section{Stephen, Makoji Roberts}

Doctoral Candidate/Researcher makeytovia@yahoo.co

\author{
Aliyu, Abdullahi \\ M.sc Candidate/Researcher \\ Department of Public Administration \\ Kogi State University, Anyigba-Nigeria
}

Doi:10.5901/mjss.2013.v4n6p113

\begin{abstract}
Nigeria's disturbing socio-economic indicators are among the worst in the world; $70 \%$ of its 148 million people vegetate below the one US dollar poverty benchmark (World Bank, 2010). It has about the worst maternal/child mortality rates in sub-Saharan Africa (NHR, 2007), it sits 143 among the 183 most corrupt countries of the world (Transparently International, 2011), and coupled with the fact that unemployment is arguably over $40 \%$ (Nigeria News Network, November 17, 2012). That these uncomplimentary indicators exists side-by-side great national wealth and potentials make the Nigerian situation a complicated paradox requiring urgent, systematic, and strategic efforts at a reversal. This paper argues that such strides should begin with reforming Nigeria's ailing public administration by way of repositioning it to both support and drive the processes of national development. It recommends, among others, purposeful political/administrative leadership, viable institutions of accountability, and huge investments in human capital development, as panacea for Nigeria's weak public administration, and impetus for sustainable national development.
\end{abstract}

Keywords: Public Administration, National Development, Human Capital Development, Public accountability, Natural Endowment.

\section{Introduction}

National development and transformation no doubt, is the most compelling challenge that today stares Nigeria hard in the face. This challenge is brought into perfect perspective with the presentation of some critical facts of our nation life. Only very few nations of the world are as endowed as Nigeria; With a population of over 148 million hard working and very resilient people, a land mass of nearly one million square kilometers that hold great potentials for all forms of agriculture, the $7^{\text {th }}$ largest producer of crude oil, the world's $5^{\text {th }}$ largest proven natural gas reserve and a plethora of solid minerals, Nigeria possess (in potentials) what it takes to be among the world's most prosperous nations.

These potentials and endowment notwithstanding, about 70\% of its citizens today live on less than US \$ 1 per day as against 15\% in 1960 (Achimugu, 2010). Indeed, this will be better understood within the knowledge that the country has earned well over US $\$ 300$ billion in the last three decades from crude oil alone (Wiwa, 2000). Similarity, of all Nigeria's power generation potentials, only $40 \%$ of its citizenry have access to electric power supply, which is most times very epileptic (NHR, 2007). Little wonder the World Bank (2005) described Nigeria as a paradox. The San Francisco Chronicle (2007) perhaps painted a more graphic picture of this Nigerian paradox, when it observed that "Nigeria is a rich 
nation floating on oil wealth but almost none of it flows to the people"

Giving the complexity of the situation at hand, attempts at reversal must be every inch systematic and strategic. It is in keeping with this line of thought that Nigerian public administration becomes a focal point, when the goal is national development. Hence, scholars like Imam (2004) and Ukpere (2006) are of the opinion that public administration and national development are strongly related such that, weak administrative machinery may never be able to play the catalyzing role it ought to play in the process of national development. Besides, such bureaucratic/administrative weaknesses could even supplant genuine efforts at national development. Newspapers and press releases are awash with issues of bureaucratic/administrative fragility, corruption, inefficiency and unethical behaviour. These deficiencies make policy implementation quite challenging and at times even impossible. For instance, as simple as the issuance of national identity card should be, the first attempt saw US \$214 million go down the drains with no body able to account for it (Daily Sun, June 14, 2010). It was discovered at some point in 2010 that N5billion was allocated to non-existent agencies in the 2010 budget (Nigeria Tribune, May 20, 2010). This happened with the active cooperation of bureaucrats. The central argument of this paper therefore is that any attempt at meaningful sustainable national development must begin with reforming, repositioning and developing the internal capacity of public administration to both support and as well drive the process of national development.

\subsection{Public Administration and National Development: The Nexus}

There is perhaps no greater issue of concern to nations of the world, especially in the third world than national transformation and development. A great deal of resources is deployed in pursuit of this goal, via a multiplicity of projects, programmes and policies. While the success of these endeavours are subjects of great debate, what stands sure is that it is a critical concern of governments across continents and geo-political divides. The reason (s) for these concerns may be many though; while some are borne out of the desire to live up to the demands and expectation of its citizenry, other are pursued in a bid to buy legitimacy, having been brought to leadership in election/political processes that do not reflect the wishes and aspirations of the people. Whatever the reasons are, what remains sure is the fact that national development is the principal pursuit as well as the public identity of contemporary public governance (Ajayi, 2008). Hence, it is accorded its rightful place. Whatever makes national development a priority, naturally underscores the need for an efficient and effective public administration. It is doubtful, judging by either historical antecedents or contemporary realities whether it is possible to achieve meaningful national development without public administration playing a catalyzing role, and the reason is not farfetched; public administration is that unit of political governance that implements the policies programmes and plans of government. As such, leaving public administration out of the process of national development is like attempting to send a message in the absence of the messenger.

Interestingly however, the problem with Nigeria is not the absence of the messenger (Public Administration) but that it is overwhelmed by a cascade of impediments that seem to incapacitate it and thereby suffocating the process of national development.

\section{Conceptual Underpinnings}

\subsection{Public Administration}

Conceptualizing public administration remains quite challenging even after several decades of development. The field therefore was been described as featuring heterodoxy rather than orthodoxy (Kautilya, 1999). These conceptual contentions notwithstanding there seem to be a point of convergence in the fact that public administration is an aspect of a more generic concept- administration, the essence of which has been described as "determined action taken in pursuit of conscious purpose" (Marx 1963).

Most efforts at defining public administration therefore stress the element of cooperation among two or more individuals, and views it as cooperative human efforts geared towards predetermined goals.

Administrative activities can take place in a variety of settings, provided the crucial elements are present: The cooperation of human beings to perform tasks that have been mutually accepted as worthy of the joint effort (Appleby, 1949). The institutional framework in which administration occurs may be as diverse as business firms, labour unions, churches, educational institutions or governmental units.

Public administration is that sector of administration found in a political setting, concerned primarily with the implementation of public policy. Public administration can be roughly distinguished from private or non-public 
administration (Henry, 1999). Of course, the range of governmental concern may vary widely from one political jurisdiction to another so that the dividing line is wavy rather than clear-cut. Kamar (2005) offers another dimension to this rather unclear identity when he argued that both fields of political science and management have had the greatest influence on public administration. Hence, it tends to share the characteristics of both, depending on the setting, and or environment.

In sum, public administration connotes the application of the principles of administration in a political setting. It is the harnessing of both human and material resources in pursuit of the implementation of government policies, goals and objectives. What seem to be of great importance to this paper is that national development rests almost entirely on public administration.

\subsection{National Development}

Just like public administration the concept of development and indeed national development has been quite nebulous mainly because of the varied views and perspective from which it is looked upon. Umezurike (2005) argues that it connotes the transformations of the nature and living condition of man as a consequence of his earlier confrontation of the constraints posed by his environment (political, economic, socio-cultural etc). Conceptualized thus, development is made to transcend the mere acquisition of the artifacts of development (Nnoli, 1981). Development is therefore primarily man-centered. Its encapsulation in national development has been its specific realization in human history. Development has also been discussed in sectoral basis including industrial, technological, urban and rural development.

However we choose to view it, national development comprises the holistic array of policies, programmes, and actions detailed in confrontation of national challenges, with the intention of improving the internal workings of government, the private sector and the entire citizenry.

The relationship between public administration and national development in Nigeria over the years therefore requires an examination.

National development is perhaps the bedrock of the agitation for self rule and many years after independence there seem to be an ever increasing agitation for national development. The futile wait for nation transformation and the release of the "all other things" that the political kingdom (independence) was expected to bring may hold a vital answer to why groups like the Niger-Delta militants and more recently Boko-Haram have made the polity quite turbulent.

Nigeria therefore is left no other alternative than to walk toward accelerated national development but then, it is doubtful if this is possible in the absence of a viable public administration. The next section therefore attempts a pathology of Nigeria public administration with the views of proffering solutions to its maladies and thereby repositioning it for national development

\section{Pathologies of Nigeria Public Administration}

Nigerian public administration has over the years been plagued by a number of problems which continue to adversely affect its role as an instrument for national development. Some of these problems are:

\subsection{The Nature of Political Competition in the Nigerian Environment}

Public service in Nigeria is today viewed as an avenue for sharing the national cake among the major ethnic groups. Hence, the unending demand for fragmentation of governmental structure i.e. (units, ministers, division of major departures etc) Ezeani (2005). Painfully these fragmentations are carried out in spite of the obvious difficulties in sustaining the existing ones (Olowu, et al., 1997). The situation is further accelerated by the public perception that the public service is amoral realm that is to be plundered to sustain individual, community and ethnic survival or other primordial grouping.

\subsection{Corruption}

Corruption is perhaps the greatest bane of the Nigerian public service. It is so endemic that it runs through from the recruitment process down to retirement. The public sector no doubt is responsible for about $80 \%$ of the vices that gives Nigeria her very high world corruption ranking.

Examples abound of top public officials in Nigeria who plunder the nation in multi millions. In 2004, the former Inspector General of Police Tafa Balogun was convicted of corruption. Though his salary was not more than $\$ 25,000$ per 
month, he had assets in Nigeria worth $\$ 150$ million and a foreign Bank account worth $\$ 6.7$ million (Ribadu, 2010). This is however a child's play in light of the Abacha family's US $\$ 600$ million loot stashed in various accounts in Switzerland. It is important to note that almost all acts of such financial hemorrhage are carried out with the active participation of career public administrators.

\subsection{Excessive Rigidity and Red-Tape}

The Nigerian public service is characterized by gross inflexibility Ezeani (2005). There is a tendency to clinging tenaciously to baseless routines and absolate laws and procedures. You may call it red tape. Katoko (1971) puts it in better perspective, "one of the major impediments to quick action can be traced to excessive layering". After a file has worked its way through the various departmental levels, the customary procedure requires that it begins all over again at the lowest clerical level, proceeding for notations through the various secretarial ranks up to the permanent secretary's desk. Procedural sluggishness and dilatory tactics at lower levels have created bottlenecks which only heroic action can break. Inflexibility not only stifles innovation it also leads to waste of time and delay in the implementation of public policies (Ezeani, 2005). National development requires a whole lot of innovative thinking and actions. Palma (1985) however argues that innovative behaviour requires an appreciable amount of flexibility and willingness to bend formal procedures to meet the task at hand. It is clear that Nigeria public administration falls far below this vital requirement.

\subsection{Poor Remuneration}

It is no more news that the wages and salaries of carrier public servants in Nigeria is alarmingly low and has in fact continued to decline over the years majorly due to a high rate of inflation and other causes. When compared with the private sector and the public services of other countries in sub-Saharan African, Nigeria's public service remuneration continues to trail behind others. There have been a number of attempts since 1998 to increase public sector minimum wage in Nigeria. General Abdulsalam Abubakar pushed minimum wage up drastically from N100.56, to N3, 479.4 another attempt saw president Olusegun Obasanjo increasing minimum wage to N5, 510 as at May 2000 and most recently in 2011, President Goodluck Jonathan increased it to 18,000 . These entire attempts never made efforts to compensate the wage erosion and starvation of many years. Besides, efforts at such wage increases could achieve little or nothing because they soon get eroded by very high inflation, and worse still they were most times beyond the budget of state governments, who are more often than not unable to pay workers at the new minimum wage, resulting in conflict between labour unions and the state governors (Salisu, 2001). This situation leaves the average Nigerian public servant demoralized, angry and ready to indulge in corrupt/ sharp practices at the slightest opportunity. This disposition in effect breads low productivity, while it suffocates national development.

\subsection{The Federal Character Principle}

In address of our diversities as a nation, the 1979 constitution of Nigeria and subsequent ones have continued to provide for a fair representation of all ethnic groups in the federal public service. This is referred to as the Federal Character Principle. The aim is to ensure that every sector of the polity is represented in the public service. As laudable as this may look, Olowu et al (1997) argues that its application, undermines democracy and excellence in the civil service. It means that the best can be left out of the service and the worst picked. This system has continued to weaken Nigerian public administration, making the processes of national development more challenging than it could otherwise have been.

\section{Repositioning Nigeria Public Administration for National Development}

The challenge of national development and transformation makes it imperative for the machinery of government responsible for it, to be re-engineered in order to meet up with the core demands of national developments. Hence, there is an urgent need to reposition public administration in Nigeria, to keep the goal of purposeful national development alive.

\subsection{Purposeful Leadership}

One of the greatest problems of Nigeria; as with other developing countries is the absence of firm and purposeful leadership, born out of integrity, hard work and sound knowledge of what to do, when, and how (Edison, 2003). It is 
perhaps against this background that a philosopher once said that "An array of rabbits led by a lion would do better than an array of lions led by a rabbit". It means that in the final analysis what matters the most is who is leading. The government should therefore ensure, (if national development would be achieved), the appointment of women and men of sound pedigree to the helm of affairs. Examples abound in Nigeria of such men and women as Nuhu Ribadu, Nasir Elrufai, Prof. Charles Soludo, Prof. Francis Idachaba, Dr.Ngozia Okojo- Iwela, Prof. Dora Akunyili, Obi Ezekwesili, and Prof. Attahiru Jega, etc.

These are outstanding Nigerian whose sense of dedication to duty and service for mother-land have gone a long way in painting at some points in our national life, glimpses of the kind of Nigeria we would like to see on a daily basis. If all other leaders understand that performance is the most enduring standard by which leaders are judged, Nigeria would be a better place.

\subsection{Empowering Institutions of Accountability}

Nigeria has a huge array of anti-corruption institutions. The list include: The Economic and Financial Crime Commission (EFCC), The Code of Conduct Bureau, the Independent Corrupt Practices and other related offenses Commission (ICPC) and the Public Complaints Commission (PCC) to mention a few. With the presence of these institutions, one is entitled to think that curbing corruption in Nigeria should have been an easy task; the paradox is however that, corruption especially in the public sector is on the increase. So much so that today, Nigeria sits among the 40 most corrupt nations of the world (Transparency International, 2010). There is therefore the need for government to make ready every bit of political will, finance, as well as the training and retraining needed to empower these institutions to be watch dogs indeed.

\subsection{Enhanced Remuneration Packages}

There is no contention over the fact that human resource is the most important of all inputs needed in the build up to achieving national development. It is in keeping with this position that contemporary writing refer to it as human capital, it therefore follows that this all-important resource must be kept steadily motivated if national development is the goal. A vital element in the motivation of human capital is no doubt the quality of remuneration packages (Lethbridge, 2004). Going by this argument Nigerian public servants are the least motivated because, their remuneration package is mostly very low and uncomplimentary. This may be a subtle affront on national development because it is not possible to use an unmotivated and demoralize public sector to drive national development. A systematic, steady and reasonable improvement of public sector remuneration would be a huge asset to Nigeria's quest for national development.

\subsection{Introducing Information and Communication Technologies (ICTs) in Public Governance.}

The bureaucratic set up of government makes performance (as defined by contemporary global demand and expectation) very challenging if not impossible (Achimugu, 2011). This is particularly the case with Nigerian public administration that still adopts traditional administrative principles in a fast moving world where speed and accuracy have become uncompromisable factors if the nation would catch up the current pace of global transformation. If accelerated nation development is the goal, incorporating and applying ICT tools in public administration becomes an urgent imperative. Moreso, because Nigerian public administration is unimaginable slow, lacks innovation and drive as well as it is weak in translating policies into reality. These are impediments that ICT tools can be antidotes to (Ifinedo, 2008).

\subsection{Investing In Human Capital Development}

In Nigeria, a great deal of the challenges that weakens the economy are births of poor quality human development and management because, education which is the catalyzing factor in both human and national development has been neglected for a couple of decades (Crueger and Lindhal, 2001; Dike, 2002). A critical look at the problems facing the Nigeria educational system would provide ready answers as to why the nation has not experienced reasonable national development.

To begin with, good quality education involves educating for character, good moral values and civic responsibility. This is what shapes the character of nations. Likona (1992), then rightly notes that respect and responsibility are the two fundamental moral values that a society should teach its citizens, others include honestly, fairness, tolerance, prudence, self discipline, helpfulness, compassion, cooperation, courage among others. It is doubtful today if $10 \%$ of Nigerian 
institutions of higher learning who are waging lost battles against examination malpractices, money for marks and sex for scores syndrome, have anything it takes to inculcates such basic but fundamental values in its graduates. Similarly, a daunting challenge facing the Nigerian educational system is that it is not positioned to meet up with the challenges of modern times. Curriculums are recycled for many decades without substantial changes, occasioned by the dynamics of a changing world. Besides, they lack the tools to produce quality graduates that are prepared to efficiently and effectively manage national affairs. A huge majority of Nigeria graduates lack the skills that drive human productivity which is pivotal to increased National wealth and development, thereby reducing unemployment, poverty, social vices and upheavals. Nigeria must therefore as a matter of urgency invest in education-driven human capital development.

\section{Concluding Remarks}

Nigeria's socio-economic woes present argent imperatives for accelerated national development. Any meaningful attempts at national development however cannot pay a slim attention to the nation's administrative machinery because it is the catalyzing factor for sustainable national development.

The attempt in this paper therefore has been not just an x-ray of Nigeria's socio-economic dislocations but suggestions at the repositioning of public administration by way of stimulating all round national development that would deal effectively with biting issues as unemployment, poverty, criminality and militancy, among others.

\section{References}

Achimugu, Hassan (2010)." Poverty Eradication and sustainable Development in Nigeria: The case of Kogi State Community and Social Development Agency" An unpublished PhD seminar of the Department of Public Administration Kogi State University AnyigbaNigeria

Achimugu, Hassan (2011). "An assessment of the contributions of e-government to overcoming the challenges of local government performance in Ofu local government area" An unpublished PhD seminar of the Department of Public Administration Kogi State University Anyigba-Nigeria

Ajayi Clement (2008). A country on the brink of collapse? London: the Accademy press.

Anazodo Peter (2009). Nigeria: The truth must be told; Ibadan: Macmillian press

Daily Sun (2010) 'PDP Chair: Jonathan under pressure to drop Nwodo,' June 14.

Dike,V.E. (Jan-March, 2002),'The State of Education in Nigeria and the Health of the Nation,'

Eziani,O. Emmanuel(2005). "The Nigerian Civil Service and National Development since independence: An Appraisal" African Journal of Political and Administrative Studies. Vol.2 No.1 pp. 167-182.

Henry, N (1992). Public Administration and Public Affairs; Eaglewood Cliffs:Prentice Hall.

Ifinedo, P (2008) 'Measuring Africa's e-redinness in the global networked economy: A nine country data analysis' International Journal of education and development using ICT. Vol.1 No.1 pp. 53-71

Kamar, B (2005)." Conceptual and Theoretical Framework" in Kamar Bello (ed.) Essentials of Public Administration. Kano: Flash Printers. Pp. 6-13

Krueger, A.B. and Mikael Lindhal (2001), 'Education for Growth, Why and for Whom?' Journal of Economic Literature Vol. 39 , no. 4 pp. $1101-136$.

Kotoko, J.Y. (1971). "Bureaucracy and Nation Building in Africa: The quarterly Journal of Administration, vol.5, No.4

Lickona, T.(October 1992), Educating for Character: How Our Schools can Teach Respect and Responsibility. New York: Bantman Books.

Nigerian Health Review (2007)." Primary Health Care in Nigeria: 30 years after Alma Ata" Health Reform Foundation of Nigeria.

Nigerian Tribune (2010),'uproar in the Senate over allocation of N5bn to non-existent agency,'May 20.

Nigerian News Agency (2012). "Is this the Nigeria of our Dreams?" November 17, 2012.

Nwosu, H.N. (1977). Political Authority and the Nigerian Civil Service. Enugu: Fourth Dimenssion Publishers.

Olowu, D. Eloho, O. and Okoni, M. (1997). "The Role of the Civil Service in Enhancing Development and Democracy: An evaluation of the Nigerian experience" A paper presented at Civil Service in Comparative Perspective, School of Public and Environmental Affairs, Indiana University, Indiana. April 5-8.

Palmer, M. (1985). Dilemas Of Development. Itahca: F.E. Peacock Publishers, Inc.

Ribadu, Nuhu (2010). My Story, My Vision; Lagos: Digital World.

Salisu, M. (2001). "Incentive Structure, Civil Service Efficiency and the Hidden Economy in Nigeria"

Transparency International (2012). World Corruption Index. www.transparencyinternational.org

The San Francisco Chronicle (2007). Elections in Nigeria. www.sanfranciscochronicle.org 